\title{
Antimicrobial D-amino acid oxidase-derived peptides specify gut microbiota
}

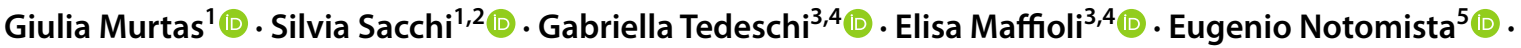

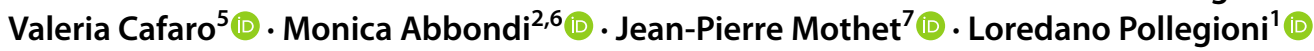

Received: 17 July 2020 / Revised: 16 December 2020 / Accepted: 30 December 2020 / Published online: 23 January 2021

(c) The Author(s) 2021

\begin{abstract}
The flavoenzyme D-amino acid oxidase (DAAO) is deputed to the degradation of D-enantiomers of amino acids. DAAO plays various relevant physiological roles in different organisms and tissues. Thus, it has been recently suggested that the goblet cells of the mucosal epithelia secrete into the lumen of intestine, a processed and active form of DAAO that uses the intestinal D-amino acids to generate hydrogen peroxide $\left(\mathrm{H}_{2} \mathrm{O}_{2}\right)$, an immune messenger that helps fighting gut pathogens, and by doing so controls the homeostasis of gut microbiota. Here, we show that the DAAO form lacking the 1-16 amino acid residues (the putative secretion signal) is unstable and inactive, and that DAAO is present in the epithelial layer and the mucosa of mouse gut, where it is largely proteolyzed. In silico predicted DAAO-derived antimicrobial peptides show activity against various Gram-positive and Gram-negative bacteria but not on Lactobacilli species, which represent the commensal microbiota. Peptidomic analysis reveals the presence of such peptides in the mucosal fraction. Collectively, we identify a novel mechanism for gut microbiota selection implying DAAO-derived antimicrobial peptides which are generated by intestinal proteases and that are secreted in the gut lumen. In conclusion, we herein report an additional, ancillary role for mammalian DAAO, unrelated to its enzymatic activity.
\end{abstract}

Keywords D-Amino acids $\cdot$ Microbiota selection $\cdot$ Novel function $\cdot$ Flavoprotein

Supplementary Information The online version contains supplementary material available at https://doi.org/10.1007/s0001 8-020-03755-w.

Loredano Pollegioni

loredano.pollegioni@uninsubria.it

Giulia Murtas

g.murtas@uninsubria.it

Silvia Sacchi

silvia.sacchi@uninsubria.it

Gabriella Tedeschi

gabriella.tedeschi@unimi.it

Elisa Maffioli

elisa.maffioli@unimi.it

Eugenio Notomista

eugenio.notomista@unina.it

Valeria Cafaro

valeria.cafaro@unina.it

Monica Abbondi

monicaabbondi@ricercaperlavita.it

Jean-Pierre Mothet

jean-pierre.mothet@universite-paris-saclay.fr
1 Department of Biotechnology and Life Sciences, University of Insubria, Via J. H. Dunant 3, 21100 Varese, Italy

2 DAAIR, D-Amino Acid International Research Center, Gerenzano, Italy

3 Department of Veterinary Medicine, University of Milan, Milan, Italy

4 Cimaina, University of Milan, Milan, Italy

5 Department of Biology, University of Naples Federico II, Naples, Italy

6 Fondazione Istituto Insubrico Ricerca Per La Vita (FIIRV), Gerenzano, Italy

7 LuMIn, Université Paris-Saclay, CNRS, ENS Paris-Saclay, CentraleSupélec, 91190 Gif-sur-Yvette, France 


\section{Introduction}

D-amino acids are natural biomolecules, components of human diet, which play specific roles; for a review, see Ref. [1]. D-amino acids are constituents of the peptidoglycan in the bacterial cell wall: their presence makes the cell wall more resistant to proteases and to some antibiotics [2]. Peptidoglycan is a dynamic structure which is modified by introducing alternative D-amino acids during stationary phase by specific periplasmic enzymatic activities $[3,4]$ : this represents a mechanism of bacteria selection.

The FAD-dependent enzyme D-amino acid oxidase (DAAO, EC 1.4.3.3) catalyzes the oxidative deamination of uncharged and basic D-amino acids [5, 6]. In mammals, DAAO is present in different organs and is expressed by many cell types. In the brain, DAAO might influence the physiology of neuronal circuits by metabolizing D-serine (D-Ser), an allosteric neuromodulator of the $\mathrm{N}$-methylD-aspartate type of glutamate receptors [7] and therefore is suspected to play a critical role in several psychiatric and neurological disorders [8, 9]. However, the highest expression and activity of DAAO are more apparent in peripheral organs and notably in the proximal tubules of the kidney, in hepatocytes, in neutrophils, and in the goblet cells and enterocytes of the small intestine $[6,10]$. In liver and kidney, DAAO is responsible for the detoxification and degradation of D-amino acids originating from the cell wall of intestinal bacteria, diet, and endogenous racemization. In neutrophils and intestinal mucosa, DAAO shows an antimicrobial activity $[11,12]$. In the intestine, DAAO is detected in the goblet cells and enterocytes of the villus epithelium [11] of the proximal and middle small intestine of mice and humans. According to a recent report, goblet cells secrete a processed and active form of mouse DAAO (mDAAO), likely due to the presence of a signal peptide and a predicted cleavage site near the $N$ terminus [11]. Then, the secreted DAAO uses intestinal D-amino acids originating from the host or from the commensal bacteria to generate bactericidal $\mathrm{H}_{2} \mathrm{O}_{2}$ to help limiting the colonization of enteropathogens including Staphylococcus aureus and Vibrio cholera.

Intriguingly, structural details support that DAAO cannot properly fold and maintain enzymatic activity (i.e., $\mathrm{H}_{2} \mathrm{O}_{2}$ production) in the absence its $N$-terminal sequence which is part of the Rossmann fold, i.e., the motif required for FAD binding. Therefore, in this work, we employed biochemical, microbial, cellular, and tissue analyses to shed light on the role of the flavoenzyme in antibacterial activity and gut homeostasis. We demonstrate that the bactericide and microbiota selective abilities of DAAO are mainly due to the generation in the gut of specific antimicrobial peptides and not by the generation of $\mathrm{H}_{2} \mathrm{O}_{2}$, as previously proposed. This investigation identifies an additional, ancillary role for mammalian DAAO, unrelated to its enzymatic activity.

\section{Results}

\section{Sequence analyses of DAAO}

To reveal the presence of a signal peptide and a cleavage site for protein secretion, the sequences of mammalian DAAOs (human, mouse, rat, and porcine) were analyzed in silico with various bioinformatics programs, including the SignalP 3.0 used by Sasabe et al. [11], see Supplemental Data 1. While the SignalP 4.1 Server predicted a signal sequence and a cleavage site between positions 16 and 17 at the $N$ terminus of the pig DAAO only (score value of 0.455 vs. a cut-off value of 0.450 ), three alternative bioinformatics tools predicted the same signal peptide for all the mammalian DAAOs analyzed, while the Signal-3L predicted the presence of this signal peptide in mouse and rat DAAOs only (Fig. 1a and Supplementary Table 1). The human DAAO, hDAAO, $(\Delta 1-16)$ variant lacking the $N$-terminal 16 residues was thus designed based on these analyses and a previous study stating that the 16 first residues correspond to a secretion signal that was removed in secreted DAAO [11].

The prediction analysis for cryptic antimicrobial peptides (CAMP) in the DAAO sequence suggests the presence of two cryptic cationic peptides, Fig. 1a. The antimicrobial absolute score, AS value which depends on hydrophobicity, net charge, and length of a peptide [13], was calculated for all possible peptides of $12-40$ residues length. The highest AS was found for a 33-residues long peptide starting at position 257 ( ${ }^{257}$ IWKSCCKLEPTLKNARIVGELTGFRPVRPQVRL ${ }^{289}$, named IWK, corresponding to ${ }^{259}$ IWEGCCKLEPTLKNARIIGERTGFRPVRPQIRL ${ }^{291}$ in the human enzyme): the AS value for this peptide is higher than two of the three threshold scores, Supplementary Fig. 1. At the $C$ terminus of DAAO, an additional region showed two relative maxima with $\mathrm{AS}=4.5$ (for the 22 residue window) and $\mathrm{AS}=3.3$ (for the 33 residue window) corresponding to peptides ${ }^{324}$ AANLFGKILEEKKLSRLPPSHL ${ }^{345}$ and ${ }^{313}$ GLTIHWGCAMEAANLFGKILEEKKLSRLPPSHL ${ }^{345}$, respectively. Even if the score of these peptides is below the threshold, we selected peptide 313-345 (named GLT and corresponding to ${ }^{315}$ GLTIHWGCALEAAKLFGRILEEKKLSRMPPSHL $^{347}$ in the human enzyme) for further characterization, because in the crystal structure of DAAO, this region is structured as a long and amphipathic $\alpha$-helix, a feature often associated with CAMPs. Notably, the T256-I257 and L289-E290 peptide bonds are both recognized by pepsin (cleavages that generate the IWK peptide), and the Y311-G312 bond is a cleavage site for both chymotrypsin 
Fig. 1 a Comparison of the primary structure of mouse, rat, porcine, and human DAAO. The putative secretion signal is marked in red, the regions recognized by anti- $N$-terminal and anti- $C$-terminal hDAAO antibodies are in purple and underlined, and putative antimicrobial sequences are in cyan and green. The regions recognized by the anti-DAAO antibodies used in Ref. [11] are highlighted in green and yellow. The peptides identified by MS analysis in the intestine samples following SDS-PAGE are highlighted in gray. b Comparison of the structure of full-length hDAAO (PDB 2DU8, green) and of the model of hDAAO $(\Delta 1-16)$ variant (blue). The deleted $N$-terminal sequence is colored in magenta
A

\begin{tabular}{|c|c|}
\hline Mouse & MRVAVIGAGVIGLSTALCIHERYHP-TQPLHMKIYADRFTPFTTSDVAAGLWQPYLSDPS \\
\hline Rat & MRVAVIGAGVIGLSTALCIHERYHP-AQPLHMKIYADRFTPFTTSDVAAGLWQPYLSDPS \\
\hline Human & MRVVVIGAGVIGLSTALCIHERYHSVLQPLDIKVYADRFTPLTTTDVAAGLWQPYLSDPN \\
\hline Porcine & $\begin{array}{l}\text { MRVVVIGAGVIGLSTALCIHERYHSVLQPLDVKVYADRFTPFTTTDVAAGLWQPYTSEPS } \\
* * * . * * * * * * * * * * * * * * * * * * \quad * * * .: *: * * * * * * *: * *: * * * * * * * * * * *: .\end{array}$ \\
\hline Mouse & NPQEAEWSQQTFDYLLSCLHSPNAEKMGLALISGYNLFRDEVPDPFWKNAVLGFRKLTPS \\
\hline Rat & NPQEAEWNQQTFDHLQSCLHSPNAEKMGLALISGYNLFRDEVPDPFWKSTVLGFRKLTPS \\
\hline Human & NPQEADWSQQTFDYLLSHVHSPNAENLGLFLISGYNLFHEAIPDPSWKDTVLGFRKLTPR \\
\hline Porcine & $\begin{array}{l}\text { NPQEANWNQQTFNYLLSHIGSPNAANMGLTPVSGYNLFREAVPDPYWKDMVLGFRKLTPR } \\
* * * * *: * * * *::^{*} *: * * *:::^{*}: * * * * *::: * * * * * * * * * * * *\end{array}$ \\
\hline Mouse & EMDLFPDYGYGWFNTSLLLEGKSYLPWLTERLTERGVKLIHRKVESLEEVAR-GVDVIIN \\
\hline Rat & ELDMFPDYSYGWFNTSLLLEGKSYLSWLTERLTERGVKFIHRKVASFEEVVRGGVDVIIN \\
\hline Human & ELDMFPDYGYGWFHTSLILEGKNYLQWLTERLTERGVKFFQRKVESFEEVAREGADVIVN \\
\hline Porcine & $\begin{array}{l}\text { ELDMFPDYRYGWFNTSLILEGRKYLQWLTERLTERGVKFFLRKVESFEEVARGGADVIIN } \\
:^{*}: * * * * * * * *: * * *: * * *::^{* *} * * * * * * * * * * *:: *^{*} *:^{* * *} . *^{*} .^{* * *}: *\end{array}$ \\
\hline Mouse & CTGVWAGALQADASLQPGRGQIIQVEAPWIKHFILTHDPSLGIYNSPYIIPGSKTVTLGG \\
\hline Rat & CTGVWAGALQADASLQPGRGQIIQVEAPWIKHFILTHDPSLGIYNSPYIIPGSKTVTLGG \\
\hline Human & CTGVWAGALQRDPLLQPGRGQIMKVDAPWMKHFILTHDPERGIYNSPYIIPGTQTVTLGG \\
\hline Porcine & $\begin{array}{l}\text { CTGVWAGVLQPDPLLQPGRGQIIKVDAPWLKNFIITHDLERGIYNSPYIIPGLQAVTLGG } \\
* * * * * * . * * * * * * * * * *:: *: * * *: *: * *: * * * . * * * * * * * * * \text { : }: * * * * *\end{array}$ \\
\hline Mouse & IFQLGNWSGLNSVRDHNT IWKSCCKLEPTLKNARIVGELTGFRPVRPQVRLEREWLHFGS \\
\hline Rat & VFQLGNWSELNSVHDHNTIWKSCCQLEPTLKNARIMGELTGFRPVRPQVRLERERLRFGS \\
\hline Human & IFQLGNWSELNNIQDHNT IWEGCCRLEPTLKNARIIGERTGFRPVRPQIRLEREQLRTGP \\
\hline Porcine & $\begin{array}{l}\text { TFQVGNWNEINNIQDHNTIWEGCCRLEPTLKDAKIVGEYTGFRPVRPQVRLEREQLRFGS } \\
* *: * * * \text {. : }:::^{* * * * * *}: \text { H }^{*}: * * * * * *::^{*}: * * * * * * * * * *: * * * * * *: *\end{array}$ \\
\hline Mouse & SSAEVIHNYGHGGYGLTIHWGCAMEAANLFGKILEEKKLSRLPPSHL \\
\hline Rat & SSAEVIHNYGHGGYGLTIHWGCAMEAANLFGKILEEKNLSRMPPSHL \\
\hline Human & SNTEVIHNYGHGGYGLTIHWGCALEAAKLFGRILEEKKLSRMPPSHL \\
\hline Porcine & $\begin{array}{l}\text { SNTEVIHNYGHGGYGLTIHWGCALEVAKLFGKVLEERNLLTMPPSHL } \\
*: * * * * * * * * * * * * * * * * * *: * * ; * * *: * * * ;: * ;: * * * *\end{array}$ \\
\hline
\end{tabular}

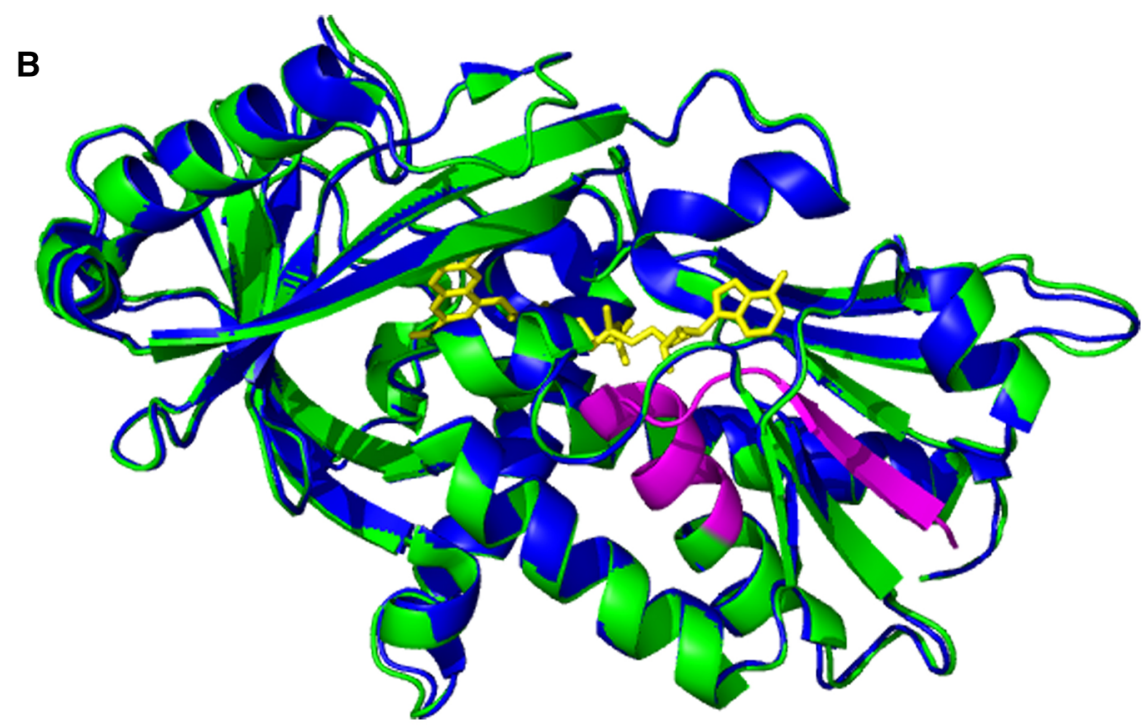

and pepsin (and generates the GLT peptide) as suggested by PeptideCutter at ExPASy website.

\section{The hDAAO $(\Delta 1-16)$ variant is unstable and inactive}

At first, hDAAO $(\Delta 1-16)$ was produced in E. coli BL21DE3Star cells using the conditions reported for the wild-type enzyme [14]: the resulting expression level in the crude extract ( $<1 \mathrm{mg} / \mathrm{L}$ fermentation broth) was too low for a biochemical characterization. To increase the expression yield of the soluble hDAAO variant, a number of experimental parameters were evaluated as well as the two-step protocol for the inhibition of protein synthesis [15]. Best conditions are reported in Supplementary Data 2 and Supplementary 
Table 2. When the hDAAO $(\Delta 1-16)$ variant was purified employing the procedure used for the wild-type enzyme [14], about $50 \%$ of the total recombinant hDAAO variant was lost in the ammonium sulfate precipitation step and part $(\sim 25 \%)$ was eluted in the flow through of the DEAE Sepharose FF column: the resulting overall purification yield was extremely low corresponding to $0.04 \mathrm{mg}$ of pure hDAAO variant/L fermentation broth. Indeed, no DAAO activity was detected in the crude extract or in the final enzyme preparation even in the presence of a saturating FAD dose, i.e., $0.2 \mathrm{mM}$.

To facilitate the production of the deleted variant, and since hDAAO is a stable homodimer in solution [14], it was co-expressed with the wild-type hDAAO using the pETDuet plasmid as tagged proteins, i.e., His-hDAAO wild-type and strep-hDAAO $(\Delta 1-16)$. No DAAO enzymatic activity was detected in the crude extract of BL21(DE3)pLysS $E$. coli cells harboring the pET-Duet vector. Neither a HiTrap chelating chromatography nor a StrepTrap column allowed binding of the recombinant proteins. None of the conditions reported in Supplementary Table 3 allowed to produce a suitable amount of hDAAO $(\Delta 1-16)$.

We next used molecular dynamics simulations to compare the stability of the tertiary structure of full-length (PDB 2E48) with the model of hDAAO $(\Delta 1-16)$ variant (Fig. 1b), in presence and in absence of the cofactor FAD. Actually, wild-type hDAAO exists in solution in equilibrium between the apoprotein and the holoenzyme forms because of the weak FAD binding $[11,16]$. The Root-Mean-Square Deviation (RMSD) during the time of simulation (100 ns) is higher for the $\Delta 1-16$ variant compared to the full-length enzyme, in particular in the absence of FAD (Fig. 2a). The Root-Mean-Square Fluctuation (RMSF), calculated to compare the extent of fluctuations of each single residue of the system, is still significantly higher for the hDAAO $(\Delta 1-16)$ (Fig. 2b). In the absence of FAD, the $\Delta 1-16$ variant resulted more unstable than the full-length protein: the regions characterized by highest instability are those located close to the flavin cofactor (residues from 17 to 50, from 135 to 210, and from 260 to 320, Fig. 2c).

Altogether, experimental and in silico analyses suggest that eliminating part of the Rossmann fold [17], and especially of the GXGXXG Wierenga sequence [18], strongly affects the overall fold of the flavoenzyme hampering FAD binding and thus catalytic activity. We concluded that elimination of 16 residues at the $N$-terminal end of hDAAO significantly hampers protein folding, FAD binding, and stability.

\section{DAAO is present in mouse intestine}

The presence of DAAO in tissue fractions from mouse and rat small intestine (luminal, mucosal content, and epithelial
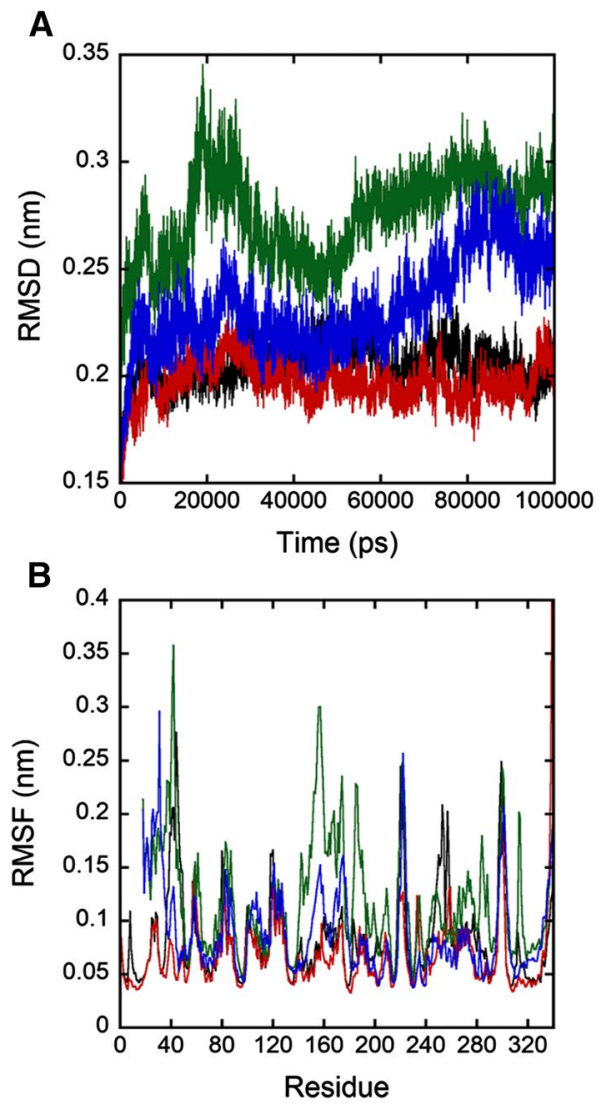

C

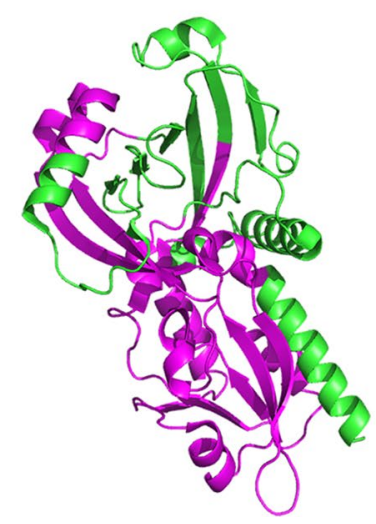

Fig. 2 a Protein RMSD from the starting structure is represented as a function of simulation time: full-length hDAAO in absence and in presence of FAD (in black and red) and hDAAO ( $\Delta 1-16)$ variant in absence and in presence of the cofactor (in green and blue). $\mathbf{b}$ The per residue RMSF values are represented as a function of the residue number (same colors as in panel a). c Model of the 3D structure of the hDAAO $(\Delta 1-16)$ variant without FAD: the sequences characterized by highest instability are colored in magenta

layer of proximal, medial, and distal small intestine) was investigated by Western blot analysis using two anti-hDAAO antibodies selected among the five available antibodies because resulted in reproducible results in pilot experiments and could provide information about the lost region, i.e., the non-commercial anti- $N$-terminal and anti- $C$-terminal 
hDAAO antibodies (from Davids Biotechnologie). The regions recognized by these antibodies are indicated in Fig. 1a. The lack of recognition by the anti- $N$-terminal antibody requires the elimination of 120 residues at the $N$ terminus, corresponding to a $13.5 \mathrm{kDa}$ decrease in mass. The elimination of a sequence $\geq 20$ residues at the $C$ terminus will result in a DAAO form that is not recognized by the anti- $C$-terminal hDAAO antibody.

The analysis of rat intestine samples resulted in nonspecific recognition patterns, see Supplementary Data 3 and Supplementary Table 4. On mice samples, the two antibodies recognize several bands, some of them at a molecular mass higher than intact DAAO, i.e., $>40 \mathrm{kDa}$. In detail, the main signals recognized by anti- $C$-terminal hDAAO antibodies correspond to bands at $70 \mathrm{kDa}$ in mucosal distal and proximal samples, at $40 \mathrm{kDa}$ in mucosal distal and luminal (proximal, medial, and distal) samples, and at $\sim 27 \mathrm{kDa}$ in mucosal proximal and distal samples; faint bands at $\sim 100 \mathrm{kDa}$ (in distal mucosal), 70, 45, and $\sim 35 \mathrm{kDa}$ (in epithelial layer samples), and at $18 \mathrm{kDa}$ (in proximal and distal mucosal samples) were also detected, see Table 1, Supplementary Data 4 and Supplementary Fig. 2A. The main signals corresponding to anti- $N$-terminal antibody recognition correspond to bands at $40 \mathrm{kDa}$ in distal samples from mucosal and luminal portions (and, with a lower intensity, from proximal and medial samples), at $35 \mathrm{kDa}$ in proximal and medial samples from mucosal and luminal fractions, and at $\leq 20 \mathrm{kDa}$ in epithelial samples (i.e., at 20 and $18 \mathrm{kDa}$ in the medial and at $15 \mathrm{kDa}$ in all samples of the epithelial fraction). Faint bands at $55 \mathrm{kDa}$ (in mucosal samples), $45 \mathrm{kDa}$ (in epithelial layer samples), and $20 \mathrm{kDa}$ (in medial and distal epithelial layer samples) were also detected. The band at $\sim 40 \mathrm{kDa}$, which should correspond to the full-length DAAO, was recognized by both anti-hDAAO antibodies in mucosal distal and luminal medial and distal regions.

To ascertain the specificity of the recognized bands in intestinal tissues, we followed the recommendations recently reported by Mothet et al. [19] by performing control analyses on intestinal tissues isolated from DAAO null constitutive mutant mice $\left(\mathrm{DAAO}^{-/-}\right)$[20]. Western blot analysis revealed bands at $27 \mathrm{kDa}$ in medial mucosa samples (and faint bands at $45 \mathrm{kDa}$ in epithelial samples, as well as at 70 and $35 \mathrm{kDa}$ in proximal epithelial samples) using the anti$C$-terminal hDAAO antibody and bands at $\sim 27$ and $20 \mathrm{kDa}$ in proximal epithelial sample by the anti- $C$-terminal hDAAO antibody (Supplementary Figs. 3 and 4). Similarly, the anti$C$-terminal mDAAO antibody recognized similar signals in samples isolated from wild-type and $\mathrm{DAAO}^{-/-}$mice (Table 1 and Supplementary Fig. 4A). Altogether, we concluded that available anti-DAAO antibodies recognize also unspecific signals.

The presence of DAAO was thus ascertained by mass spectrometry analysis: the bands at 40 and $27 \mathrm{kDa}$ of the distal mucosa, and the $\sim 27 \mathrm{kDa}$ band of the proximal mucosa showed peptides derived from DAAO (three, four, and three, respectively). In the epithelial samples, the 27, 18 , and $15 \mathrm{kDa}$ bands of the medial fraction all contained DAAO-derived peptides (Fig. 3 and Supplementary Data 5 and Supplementary Table 5). No peptides deriving from DAAO were identified in the 70 and $45 \mathrm{kDa}$ bands of the medial mucosa and in the $\sim 35 \mathrm{kDa}$ band from proximal mucosa, as well as from $\mathrm{DAAO}^{-1-}$ mice samples (i.e., the $40 \mathrm{kDa}, \sim 35 \mathrm{kDa}$, and $\sim 27 \mathrm{kDa}$ bands from proximal and distal mucosa). Furthermore, mass spectrometry analysis identified DAAO in mucosal distal, medial, and proximal samples from wild-type mice, while no DAAO-derived peptide was identified in the same samples from $\mathrm{DAAO}^{-/-}$mice (Supplementary Table 6).

Altogether, our results indicate that DAAO is released in the lumen of mouse gut, where it is largely proteolyzed. Peptidomic analysis was performed on mucosal samples of wild-type and $\mathrm{DAAO}^{-/-}$mice seeking for the putative 313-345 and 257-289 CAMPs. In wild-type mice, the putative antimicrobial $C$-terminal GLT peptide was detected in mucosal samples, especially in the distal fraction (alternative peptides started from residues $314,315,322$, and 323), and part of the IWK (the peptide 268-290) in the proximal fraction, Table 2. No peptides originating from DAAO were identified in the $\mathrm{DAAO}^{-/-}$mice.

Although we confirm the secretion of DAAO in the intestinal lumen, some discrepancies are apparent with previously reported observations [11]. We could detect neither the full-length mouse DAAO in the epithelial layer nor the $\sim 35-37 \mathrm{kDa}$ protein form lacking the $N$-terminal sequence in the intestinal content. Only bands at $\leq 27 \mathrm{kDa}$, too small to preserve the enzymatic activity, were instead apparent in both studies. We can not exclude that the use of germ free C57BL/6 mice [11] instead of untreated C57BL/6 mice, as in our case, could have altered the expression of DAAO.

The antimicrobial effect of DAAO in gut was previously related to its catalytic activity [11]. We assayed DAAO activity level by zymograms performed following native PAGE and the sensitive Amplex UltraRed method (Supplementary Data 6). Zymograms on mice intestinal samples showed a faint positive band at low electrophoretic mobility, significantly different from the one observed for the reference recombinant hDAAO and from the signal observed using a mice cerebellum sample (Supplementary Fig. 5A, B). Such an activity signal was also apparent in samples from $\mathrm{DAAO}^{-/-}$mice (Supplementary Fig. 5D, E) or when the substrate D-alanine was omitted from the developing mixture (Supplementary Fig. 5C, F), pointing to aspecific/ background signals. The signal recorded using the Amplex UltraRed method is identical with or without the substrate D-alanine or by adding 6-chloro-1,2-benzisoxazol-3(2H)-one 
Table 1 Schematic recognition pattern obtained using different antibodies in Western blot analyses on mouse intestinal tissues (see Suppl. Data 4)

\begin{tabular}{|c|c|c|c|c|c|}
\hline \multirow[t]{2}{*}{ Model } & \multirow[t]{2}{*}{ MW (kDa) } & \multicolumn{2}{|l|}{$\alpha$-hDAAO-Nterm (DaBio) } & \multicolumn{2}{|c|}{$\begin{array}{l}\alpha \text {-hDAAO-Cterm (DaBio) }[\alpha \text {-mDAAO-Cterm (Santa } \\
\text { Cruz)] }\end{array}$} \\
\hline & & Sample & Intensity & Sample & Intensity \\
\hline \multirow[t]{10}{*}{ Mouse wild type } & 100 & & & Distal mucosa & $*$ \\
\hline & 70 & & & $\begin{array}{l}\text { Proximal mucosa, medial } \\
\text { mucosa, distal mucosa, } \\
\text { epithelial layer (proximal, } \\
\text { medial, distal) }\end{array}$ & $* *, * * * *, * *, *$ \\
\hline & 55 & $\begin{array}{l}\text { Mucosa (proximal, medial, } \\
\text { distal) }\end{array}$ & * & $\begin{array}{l}\text { (Distal mucosa), (proximal } \\
\text { mucosa) }\end{array}$ & $(* *),(* * *)$ \\
\hline & 45 & $\begin{array}{l}\text { Proximal epithelial, epithe- } \\
\text { lial (medial, distal) medial } \\
\text { mucosa }\end{array}$ & $* *, *$ & $\begin{array}{l}\text { Epithelial layer (proximal, } \\
\text { medial, distal) }\end{array}$ & * \\
\hline & 40 & $\begin{array}{l}\text { Distal mucosa, luminal } \\
\text { medial, proximal distal } \\
\text { lumen }\end{array}$ & $* *, * / * *, * * *$ & $\begin{array}{l}\text { Distal mucosa, luminal } \\
\text { (proximal, medial, distal) }\end{array}$ & $* *, * / * *$ \\
\hline & $\sim 35-37$ & $\begin{array}{l}\text { Proximal mucosa, medial } \\
\text { mucosa, proximal lumen, } \\
\text { medial lumen }\end{array}$ & $* * / * * *, * / * *, * *, *$ & $\begin{array}{l}\text { Epithelial layer (proximal, } \\
\text { medial, distal), (distal, } \\
\text { proximal mucosa) }\end{array}$ & $*,(* *)$ \\
\hline & 27 & Medial epithelial layer & & $\begin{array}{l}\text { Proximal mucosa, distal } \\
\text { mucosa }\end{array}$ & $* * / * * * /(* *), * * * / * * * * /(* *)$ \\
\hline & 20 & $\begin{array}{l}\text { Proximal epithelial layer, } \\
\text { epithelial layer (medial, } \\
\text { distal) }\end{array}$ & $* * * *, *$ & & \\
\hline & 18 & Distal epithelial layer & $* * *$ & Mucosa (proximal, distal) & $*$ \\
\hline & 15 & $\begin{array}{l}\text { Epithelial layer (proximal, } \\
\text { medial, distal) }\end{array}$ & $*$ & & \\
\hline \multirow[t]{8}{*}{ Mouse DAAO ${ }^{-/-}$} & 70 & & & Proximal epithelial & $*$ \\
\hline & 55 & & & (Proximal, distal mucosa) & $(* *)$ \\
\hline & 45 & Distal mucosa & $*$ & $\begin{array}{l}\text { Epithelial layer (proximal, } \\
\text { medial, distal) }\end{array}$ & $*$ \\
\hline & 40 & $\begin{array}{l}\text { Distal mucosa, proximal } \\
\text { mucosa }\end{array}$ & $*, *$ & & \\
\hline & $\sim 35-37$ & $\begin{array}{l}\text { Proximal mucosa, distal } \\
\text { mucosa }\end{array}$ & $*, *$ & $\begin{array}{l}\text { Distal mucosa, (proximal } \\
\text { mucosa) }\end{array}$ & $* * * /(*),(*)$ \\
\hline & 27 & $\begin{array}{l}\text { Distal mucosa, proximal } \\
\text { epithelial layer }\end{array}$ & $*, * * *$ & $\begin{array}{l}\text { (Proximal mucosa), (distal } \\
\text { mucosa) }\end{array}$ & $(*),(* * *)$ \\
\hline & 18 & Mucosa distal & $*$ & & \\
\hline & 15 & Mucosa distal & * & & \\
\hline
\end{tabular}

The bands indicated in bold have been analyzed by MS: the underlined samples contain DAAO-derived peptides (see Fig. 3). Samples with no asterisk were not recognized by Western blot analysis, but were analyzed by MS

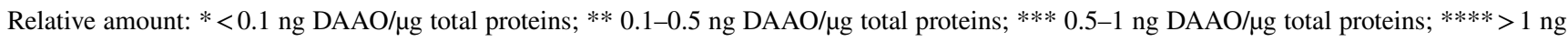
$\mathrm{DAAO} / \mu \mathrm{g}$ total proteins

(CBIO), an inhibitor of hDAAO [21]: it is close to the detection limit for all tested samples (Supplementary Fig. 6) and four orders of magnitude lower than the value of recombinant hDAAO. In a previous report, DAAO activity was evaluated on intestine tissues by a histological method using a coupled assay with peroxidase and D-proline as substrate [11], a molecule that is also oxidized by alternative enzymes such as D-aspartate oxidase. Most importantly, this latter work identified DAAO activity in epithelial cells only, not in extracellular space. In conclusion, we exclude the presence of active DAAO in mouse gut at a detectable level.

\section{DAAO-derived CAMPs show antimicrobial activity}

Investigating the primary structure of mDAAO using the method described in Pane et al. [13] suggests the presence of two antimicrobial peptides corresponding to 257-289 (IWK) and 315-347 (GLT) regions, see Fig. 1a. Conformation of 
A Distal mucosal

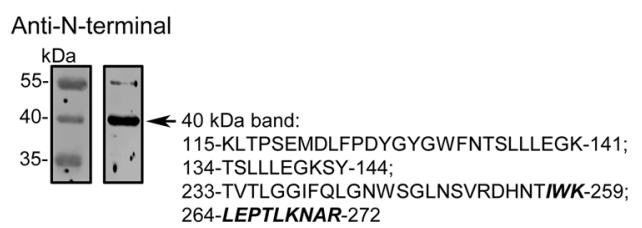

Anti-C-terminal

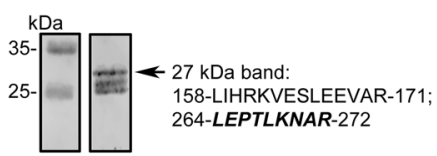

B Proximal mucosal

Anti-C-terminal

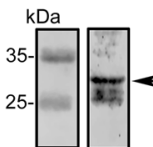

$27 \mathrm{kDa}$ band:

233-TVTLGGIFQLGNWSGLNSVRDHNTIWK-259;

296-HGSSSAEVIHNYGHGGYGLTIHWGCAMEAANLFGKILEEK-335

C Medial epithelial layer

Anti-N-terminal

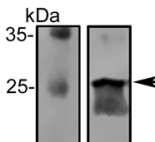

$25 \mathrm{kDa}$ band:

08-NAVLGFRKLTPSEMDLFPDYGYGWFNTSLLLEGK-141 108-NAVLGFR-;

151-LTERGVK-157

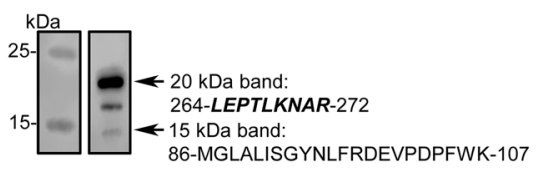

Fig. 3 Western blot and MS analysis of distal (a) and proximal (b) mucosal contents and of medial epithelial layer (c) of mouse intestinal samples. The bands recognized by the different antibodies (see arrows) were analyzed by MS/MS for the presence of DAAO: the peptides identified are reported (right side). The sequence belonging to the antimicrobial peptides are shown in bold

DAAO antimicrobial peptides was analyzed by far-UV CD. Both the peptides are mostly unstructured and show slightly different spectra (Supplementary Data 7 and Supplementary
Fig. 7, black lines). Notably, they assume an ordered helical conformation (minima at around 210 and $220 \mathrm{~nm}$ ) in the presence of SDS $(1 \mathrm{mM})$ or TFE $(30 \% \mathrm{v} / \mathrm{v})$, two membrane mimicking agents, and of LPS from E. coli $(0.1$ and $0.25 \mathrm{mg} /$ $\mathrm{mL}$ for GLT and IWK, respectively) (Supplementary Fig. 7). DichroWeb confirmed the experimental results: both the peptides are initially "unordered" and assume helical conformation during the titration ( $\alpha$-helix content $>70 \%)$.

To shed light on their putative role in gut microbial selection, the antimicrobial activity of the two polypeptides and a mixture containing both peptides at a 1:1 molar ratio was tested on two Gram-positive and five Gram-negative bacteria (Table 3). Both peptides showed bactericidal or bacteriostatic activity on the tested bacteria, the only exception was Salmonella enteritidis. In some cases, an additive effect of the two peptides was apparent reaching MIC values in the low micromolar range. Noteworthy, both peptides showed a strong and additive bacteriostatic activity on E. faecalis with the mixture of the two peptides being already active at about $3 \mu \mathrm{M}$.

Four lactic acid bacteria strains belonging to species Lactobacillus acidophilus, L. casei, L. fermentum, and $L$. rhamnosus were tested for their susceptibility to IWK and GLT peptides using broth microdilution (Table 3). The tested strains did not show any significant difference in their antibiotic resistance profile (all strains were resistant to vancomycin and susceptible to erythromycin) and were no sensitive to IWK and GLT peptides in vitro at the highest tested concentration of $100 \mu \mathrm{M}$.

For sake of comparison, the antimicrobial activity was also tested on selected Gram-positive and Gram-negative strains using the peptides identified in the mucosal sample, i.e., the 268-290 (LKN), 315-345 (TIH), and 323-345 (EAA) peptides (Tables 2 and 3). The TIH peptide behaved similarly to the GLT peptide, while the EAA shorter version (lacking the $N$-terminal portion) did not show any antibacterial activity. On the other hand, the LKN peptide was less effective than the longer IWK one (residues 257-289) but,
Table 2 DAAO originating peptides identified in mucosal samples from wild-type and $\mathrm{DAAO}^{-/-}$mice

\begin{tabular}{|c|c|c|c|c|c|c|}
\hline & \multicolumn{3}{|l|}{ Wild-type } & \multicolumn{3}{|l|}{$\mathrm{DAAO}^{-/-}$} \\
\hline & Proximal & Medial & Distal & Proximal & Medial & Distal \\
\hline $313-345^{\mathrm{a}}$ & - & $\mathrm{X}$ & $\mathrm{X}$ & - & - & - \\
\hline $314-345$ & - & - & $\mathrm{X}$ & - & - & - \\
\hline $315-345$ (TIH) & - & - & $\mathrm{X}$ & - & - & - \\
\hline $322-345$ & - & - & $\mathrm{X}$ & - & - & - \\
\hline 323-345 (EAA) & - & - & $\mathrm{X}$ & - & - & - \\
\hline $268-290^{\mathrm{b}}(\mathrm{LKN})$ & $\mathrm{X}$ & - & - & - & - & - \\
\hline
\end{tabular}

Only peptides identified with high confidence and Xcorr $\geq 1.5$ have been considered (indicated with $\mathrm{X}$, while - means not found)

${ }^{\text {a }} \mathrm{N} 326$ deamination and M322 oxidation modifications have been considered

${ }^{\mathrm{b}} \mathrm{N} 270$ deamination and M322 oxidation modifications have been considered 
Table 3 Antimicrobial activity expressed as MIC and MBC values of two putative CAMPs derived from mouse DAAO on bacteria and lactobacilli

\begin{tabular}{|c|c|c|c|c|c|c|c|}
\hline Bacterial strain & Peptide/antibiotic & $\mathrm{MIC}(\mu \mathrm{M})$ & $\operatorname{MBC}(\mu \mathrm{M})$ & MBC/MIC & $\begin{array}{l}\text { Bacte- } \\
\text { ricidal } \\
\text { activity }\end{array}$ & $\begin{array}{l}\text { Bacte- } \\
\text { riostatic } \\
\text { activity }\end{array}$ & $\mathrm{MIC}(\mu \mathrm{g} / \mathrm{mL})$ \\
\hline \multicolumn{8}{|l|}{ Gram-negative } \\
\hline \multirow[t]{4}{*}{ Pseudomonas aeruginosa $\mathrm{PAO} 1$} & IWK & 25 & 50 & 2 & Yes & & \\
\hline & GLT & 100 & $>100$ & - & & & \\
\hline & IWK + GLT & 12.5 & 50 & 4 & Yes & & \\
\hline & Polymyxin B & & & & & & 0.25 \\
\hline \multirow[t]{4}{*}{ Acinetobacter baumanii ATCC 17878} & IWK & 12.5 & 12.5 & 1 & Yes & & \\
\hline & GLT & 50 & 50 & 1 & Yes & & \\
\hline & IWK + GLT & 12.5 & 25 & 2 & Yes & & \\
\hline & Polymyxin B & & & & & & 0.5 \\
\hline \multirow[t]{8}{*}{ Escherichia coli ATCC 25922} & IWK & 12.5 & 12.5 & 1 & Yes & & \\
\hline & LKN & 50 & 50 & 1 & Yes & & \\
\hline & GLT & 25 & 25 & 1 & Yes & & \\
\hline & $\mathrm{TIH}$ & 25 & 25 & 1 & Yes & & \\
\hline & EAA & $>200$ & - & - & & & \\
\hline & IWK + GLT & 12.5 & 100 & 8 & & Yes & \\
\hline & $\mathrm{TIH}+\mathrm{LKN}$ & 12.5 & 12.5 & 1 & Yes & & \\
\hline & Polymyxin B & & & & & & 0.5 \\
\hline \multirow[t]{8}{*}{ Salmonella typhimurium ATCC 14028} & IWK & 25 & 50 & 2 & Yes & & \\
\hline & LKN & $>200$ & - & - & & & \\
\hline & GLT & 25 & $>100$ & $>4$ & & Yes & \\
\hline & TIH & 25 & $>200$ & $>4$ & & Yes & \\
\hline & EAA & $>200$ & - & - & & & \\
\hline & IWK + GLT & 6.25 & 100 & 16 & & Yes & \\
\hline & $\mathrm{TIH}+\mathrm{LKN}$ & 25 & 25 & 1 & Yes & & \\
\hline & Polymyxin B & & & & & & 0.12 \\
\hline \multirow[t]{4}{*}{ Salmonella enteritidis 706 RIVM } & IWK & 100 & - & - & & & \\
\hline & GLT & 100 & - & - & & & \\
\hline & IWK + GLT & 50 & - & - & & & \\
\hline & Polymyxin B & & & & & & 0.5 \\
\hline \multicolumn{8}{|l|}{ Gram-positive } \\
\hline \multirow[t]{4}{*}{ Staphylococcus aureus ATCC 6538P } & IWK & 25 & 50 & 2 & Yes & & \\
\hline & GLT & $>100$ & - & - & & & \\
\hline & IWK + GLT & 25 & 50 & 2 & Yes & & \\
\hline & Vancomycin & & & & & & 0.5 \\
\hline \multirow[t]{8}{*}{ Enterococcus faecalis ATCC 29212} & IWK & 12.5 & $>100$ & $>4$ & & Yes & \\
\hline & LKN & $>200$ & - & - & & & \\
\hline & GLT & 6.25 & $>100$ & $>4$ & & Yes & \\
\hline & $\mathrm{TIH}$ & 12.5 & $>200$ & $>4$ & & Yes & \\
\hline & EAA & $>200$ & - & - & & & \\
\hline & IWK + GLT & 3.12 & $>100$ & $>4$ & & Yes & \\
\hline & $\mathrm{TIH}+\mathrm{LKN}$ & 12.5 & $>200$ & $>4$ & & Yes & \\
\hline & Vancomycin & & & & & & 2 \\
\hline Lactobacilli (MIC, $\mu \mathrm{M}$ ) & \multicolumn{2}{|c|}{ L. fermentum ATCC 14931} & \multicolumn{2}{|c|}{ L. casei ATCC 393} & \multicolumn{2}{|c|}{ L. rhamnosus ATCC 7469} & $\begin{array}{l}\text { L. acidophi- } \\
\text { lus ATCC } \\
4356\end{array}$ \\
\hline IWK & $>110$ & & $>110$ & & 110 & & $>110$ \\
\hline GLT & $>100$ & & $>100$ & & 100 & & $>100$ \\
\hline
\end{tabular}


Table 3 (continued)

\begin{tabular}{llccc}
\hline Lactobacilli $(\mathrm{MIC}, \mu \mathrm{M})$ & L. fermentum ATCC 14931 & L. casei ATCC 393 & $\begin{array}{c}\text { L. rhamnosus ATCC 7469 } \\
\text { L. acidophi- } \\
\text { lus ATCC } \\
4356\end{array}$ \\
\hline Erythromycin & 1.4 & 2.8 & 0.7 & 0.7 \\
Vancomycin & $>100$ & $>100$ & $>100$ & $>100$ \\
\hline
\end{tabular}

when used in combination with the TIH showed a significant additive effect. These results confirm the strong and additive antibacterial activity of peptides generated from DAAO.

\section{Discussion}

DAAO is known to be a peroxisomal enzyme [22-24] even if it was detected in cytosol (i.e., the neo-synthetized protein) $[23,25]$ and in the nuclei of proximal tubule epithelial cells following treatment with the drug propiverine [26]. Indeed, DAAO was also reported to be secreted in the intestine by goblet cells thanks to the presence of a signal peptide and a predicted cleavage site near the $N$ terminus [11]. Interestingly, it was proposed that intestinal processed and active DAAO might control the homeostasis of gut microbiota through the production of $\mathrm{H}_{2} \mathrm{O}_{2}$ using D-amino acids arising from diet and bacteria. Recently, we reported the antimicrobial activity on food specimen of a very active, recombinant DAAO from yeast establishing that it is indeed due to $\mathrm{H}_{2} \mathrm{O}_{2}$ production [27]. Here, we demonstrate that the DAAO form lacking the 16 first amino acid residues is unstable and inactive. Accordingly, any active DAAO species present in the lumen might retain the $N$-terminal sequence required for cofactor binding. Native-PAGE and activity assays excluded the presence of an active DAAO form in mouse gut, in agreement with a recent investigation on DAAO activity in whole intestine as well as proximal, middle, and distal fractions [28]. From Western blot and MS/MS analyses on small intestine mice samples, we concluded that DAAO is present in the epithelial layer and in the mucosal fraction of mouse gut, where it is largely proteolyzed. Altogether, our results exclude $\mathrm{H}_{2} \mathrm{O}_{2}$ generated by DAAO reaction as the mechanism for microbial selection in the gut.

The antimicrobial AS score [29-31] recognized two internal regions in DAAO sequence as CAMPs. The corresponding peptides assumed a secondary structure in the presence of detergents and LPS from E. coli and showed antimicrobial activity on various Gram-positive and Gram-negative bacteria but not on Lactobacilli species, which represent the commensal microbiota. The IWK and GLT peptides (and their derivatives TIH and LKN) have been identified in the mucosal fractions. Accordingly, we propose that DAAO selects the gut microbiota through antimicrobial peptides generated by intestinal proteases instead of a direct action based on its catalytic activity and production of $\mathrm{H}_{2} \mathrm{O}_{2}$. An antibacterial activity of DAAO was previously proposed in leukocytes $[32,33]$. Our work adds a new function to the physiological roles played by DAAO in mammals, ranging from control on NMDA receptor functionality in the central nervous system acting on D-serine level, to the elimination of D-amino acids in kidney and to the antibacterial activity in neutrophilic leukocytes [5].

Furthermore, since D-amino acids alter the peptidoglycan wall [3] and their level is affected by both nutrients and DAAO activity (as confirmed by the higher D-alanine level observed in $\mathrm{DAAO}^{-/-}$mice) [11], we suggest that DAAOderived antimicrobial peptides and D-amino acids act independently on microbiota selection in the gut (Fig. 4). An intriguing relationship between gut microbiota and D-amino acids may be potentially identified in neurodegenerative diseases, based on alterations in D-serine and D-glutamate levels in Alzheimer's disease and other forms of dementia [34, 35].

\section{Methods}

\section{Molecular dynamics of hDAAO}

The 3D structure of the substrate-free form of the human DAAO (hDAAO, PDB 2E48) was used as a starting point for molecular dynamics (MD) simulation performed using the GROMACS package, version 4.6.7. The model of the deleted variant was obtained from the structure of full-length hDAAO through the deletion of the first $N$-terminal 16 residues. For the full-length hDAAO, the system was solvated in a cubic box (volume equal to $670 \mathrm{~nm}^{3}, 8.5 \times 7.5 \times 10.5 \mathrm{~nm}$ ) with 20,000 water molecules, while for the deleted variant, a dodecahedral box was used (volume of $610 \mathrm{~nm}^{3}$ ) and solvated with 18,000 water molecules, with the aim to decrease the system dimensions and to increase the rate of simulation. To neutralize the overall charge, an adequate number of $\mathrm{Na}^{+}$ions were added. The system was minimized again with the Steepest Descent method, followed by equilibration of the restrained protein $\left(1000 \mathrm{~kJ} \mathrm{~mol}^{-1} \mathrm{~nm}^{-2}\right.$ isotropic force applied to each heavy atom of the protein) in the NVT ensemble (up to $200 \mathrm{ps).} \mathrm{In} \mathrm{each} \mathrm{system,} \mathrm{the}$ equilibration phase was composed of an inverted simulated annealing starting with an initial temperature of $10 \mathrm{~K}$ and rising up to $300 \mathrm{~K}$ in $200 \mathrm{ps}$, keeping the heavy atoms of 
Fig. 4 Mode of action proposed for DAAO (produced by epithelial layer cells) in the selection of intestinal microbiota based on antimicrobial peptides generated by proteolytic digestion of the flavoenzyme (starting intracellularly and fulfilled at the extracellular level in the lumen). Microbiota selection can also arise from D-amino acids originating from commensal microbiota and food
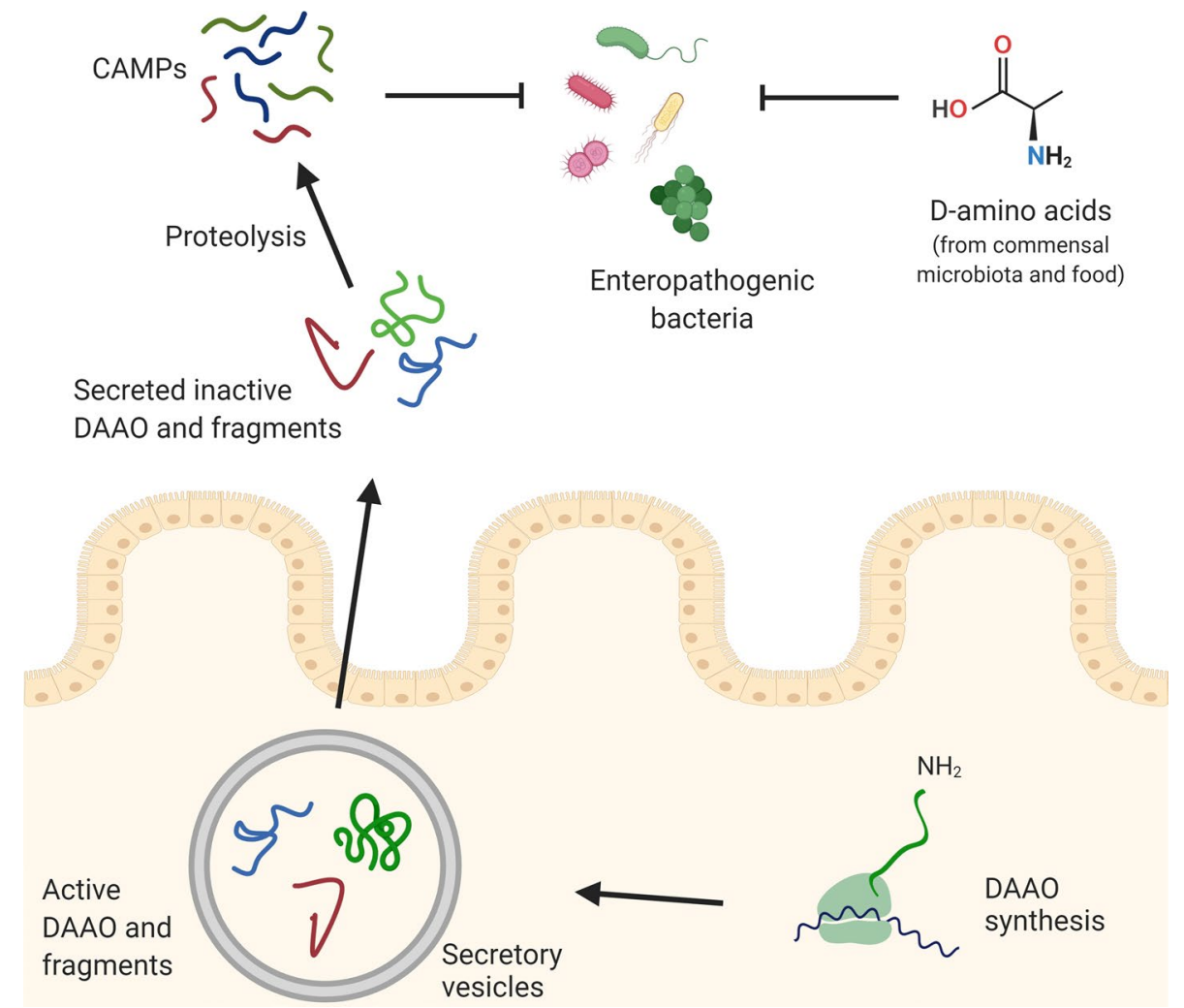

protein restrained in the same way as in the protein systems. In production phase, each system was simulated for $100 \mathrm{~ns}$ in unrestrained conditions in NVT ensemble. Electrostatics was treated with the cut-off method for short-range interactions and with the Particle Mesh Ewald method for the longrange ones (rlist $=1.1 \mathrm{~nm}$, cut-off distance $=1.1 \mathrm{~nm}, \mathrm{VdW}$ distance $=1.1 \mathrm{~nm}, \mathrm{PME}$ order $=4$ ). A time step of $2 \mathrm{fs}$ was set using bond-constraining algorithm LINKS. The constant temperature conditions were provided using $V$-rescale thermostat, which is a modification from Berendsen's coupling algorithm. The AMBER99SB-ILDN force field was used for the simulations.

The Root-Mean-Square Deviation of atomic positions (RMSD, the measure of the average distance between the atoms) was used as a quantitative measure of similarity to compare the stability of the systems (full-length vs. deleted hDAAO variant) in presence or in absence of the flavin cofactor with respect to the initial reference structure. The Root-Mean-Square Fluctuation (RMSF, the measure of the deviation between the positions of a residue averaged over time) was calculated to compare the fluctuations of every single residue in the systems.

\section{Antibacterial peptides}

The sequences of murine and human DAAO were analyzed by an in silico tool [13] which allows to detect the presence and the accurate position of a potential cryptic antimicrobial peptide (CAMP) inside a protein, based on antibacterial "absolute score" (AS) which depends on hydrophobicity, net charge, and length of a peptide. Putative antimicrobial peptides identified inside the sequence of mouse DAAO, ${ }^{257}$ IWKSCCKLEPTLKNARIVGELTGFRPVRPQVRL ${ }^{289}$ (IWK) and ${ }^{313}$ GLTIHWGCAMEAANLFGKILEEKKLSRLPPSHL ${ }^{345}$ (GLT) were synthesized by Aurogene s.r.l. (Roma, Italy), and the ${ }^{268}$ LKNARIVGELTGFRPVRPQVRLE $^{290}$ (LKN), ${ }^{323}$ EAANLGGKILEEKKLSRLPP$\mathrm{SHL}^{345}$ (EAA), and ${ }^{315}$ TIHWGCAMEAANLFGKILEEKKLSRLPPSHL $^{345}$ (TIH) by Microtech s.r.l. (Napoli, Italy).

MIC (Minimum Inhibitory Concentration) analyses were performed on Gram-positive and Gram-negative bacteria by a broth microdilution method previously described [13], with minor modifications. In details, assays were carried out in Nutrient Broth $0.5 \times$ (Difco, Detroit, MI, USA) using sterile 96-well polypropylene microtiter plates (cat. 3879, Costar Corp., Cambridge, MA, USA). Bacterial strains were grown in Luria-Bertani (LB) medium overnight at $37{ }^{\circ} \mathrm{C}$ and then diluted in nutrient broth at a final concentration of $\sim 5 \times 10^{5} \mathrm{CFU} / \mathrm{mL}$ per well. IWK and GLT peptides were suspended in $5 \mathrm{mM}$ sodium acetate buffer, $\mathrm{pH}$ 5. Peptide concentrations were determined by spectrophotometric analysis using the extinction coefficients calculated by the ProtParam tool (http://web.expasy.org/protparam/). Twofold serial dilutions of peptides were carried out in the test wells 
(0.2-100 $\mu \mathrm{M}$ concentration range). Plates were incubated overnight at $37^{\circ} \mathrm{C}$. MIC value was taken as the lowest concentration at which growth was inhibited. Three independent experiments were performed for each MIC value. The peptide antibiotic polymyxin B and vancomycin (Sigma, St. Louis, MO) were tested as control. MIC values were measured on: Pseudomonas aeruginosa PAO1, Acinetobacter baumanii ATCC 17878, Escherichia coli ATCC 25922, Salmonella typhimurium ATCC 14028, Salmonella enteritidis 706 RIVM (kindly provided by Prof. E. Veldhuizen, Utrecht University, Holland), Staphylococcus aureus ATCC 6538P, and Enterococcus faecalis ATCC 29212.

The Minimum Bactericidal Concentration (MBC) was determined from the broth dilution of MIC tests by subculturing cell mixtures on agar plates. The MBC was defined as the lowest concentration of antibacterial agent that kills $\geq 99.9 \%$ of bacterial cells. According to a widely accepted criterion, peptides were considered bactericidal if their MBC was no more than four times the MIC.

To assess the effect of antibacterial peptides on lactobacilli, Lactobacillus acidophilus ATCC 4356, Lactobacillus casei ATCC 393, Lactobacillus fermentum ATCC 14931, and Lactobacillus rhamnosus ATCC 7469 strains (from American Type Culture Collection) were used. Before performing the test, cultures were streaked on Lactobacilli MRS agar (MRS) and incubated for $24 \mathrm{~h}$ at $37^{\circ} \mathrm{C}$ in an anaerobic chamber (BD Difco, Detroit, MI, USA). Antibacterial susceptibility testing was performed according to the ISO 10932/IDF 233 standard (ISO, 2010). Erythromycin and vancomycin (Sigma-Aldrich, USA) stock solutions were prepared at a concentration of $1 \mathrm{mM}$, and IWK and GLT peptides at $400 \mu \mathrm{M}$. Typically, a twofold serial dilution of stock solutions was performed in Lactobacilli MRS broth to obtain solutions in the $0.2-100 \mu \mathrm{M}$ concentration range. Bacterial inocula were prepared by suspending colonies, from $24 \mathrm{~h}$ incubated Lactobacilli MRS agar plates, into $2 \mathrm{~mL}$ of $0.85 \% \mathrm{NaCl}$ solution. Subsequently, inocula were adjusted to have an $\mathrm{OD}_{625 \mathrm{~nm}}$ of 0.25 and diluted 1:200 in Lactobacilli MRS broth for inoculation of microdilution plates by adding $50 \mu \mathrm{L}$ of diluted inoculum to each well containing $50 \mu \mathrm{L}$ of an antibiotic/peptide solution (the bacterial inoculum was around $3-8 \times 10^{5} \mathrm{CFU} / \mathrm{mL}$ in the wells). MIC values were estimated after incubating the plates under anaerobic conditions at $37^{\circ} \mathrm{C}$ for $48 \mathrm{~h}$.

\section{Preparation of $h D A A O(\Delta 1-16)$ deletion variant in Escherichia coli}

The cDNA encoding the $N$-terminal deleted variant lacking the secretion signal peptide, namely hDAAO $(\Delta 1-16)$, was prepared by PCR using the pET11b-His-hDAAO plasmid, as detailed in Supplemental Data 2. For the co-expression of hDAAO $(\Delta 1-16)$ variant with the His-tagged full-length
hDAAO, the pET-Duet-1 vector (Novagen, Darmstadt, Germany) was used. Recombinant hDAAO wild-type and deleted variants were expressed in BL21(DE3)Star E. coli cells and purified as reported in Ref. [14]; $40 \mu \mathrm{M}$ of free FAD was present during all purification steps. The coexpressed deleted variant and full-length hDAAO (which were expected to produce heterodimers) were purified using the protocol setup for the His-tagged hDAAO (by HiTrap chelating chromatography) or the protocol suggested for the purification of strep-tagged protein (by strep-trap HP chromatography) for the strep-tagged hDAAO $(\Delta 1-16)$. DAAO activity was assayed with an oxygen electrode at $\mathrm{pH} 8.5$, air saturation, and $25^{\circ} \mathrm{C}$, using $28 \mathrm{mM}$ D-alanine as substrate in the presence of $0.2 \mathrm{mM}$ FAD [14].

\section{Isolation of luminal, mucosal, and epithelial layers in the small intestine}

Slightly modified version of the protocol described in Vaishnava et al. [36] was used to isolate luminal and mucosal layers in the small intestine of Wistar rats ( 2 males and 2 females, 2-3 months old) and C57BL/6 J mice (2 males and 1 female, 2-3 months old). The protocol reported in Ref. [37] was followed for isolation of the epithelial layer. Freshly dissected rat or mouse small intestines were partitioned into three regions: proximal, medial, and distal samples. Then each piece was further subdivided into three parts: (i) the 'luminal content' corresponded to the washing out with $2 \mathrm{~mL}$ of ice-cold sterile phosphate buffer saline (PBS); (ii) the tissue pieces were opened longitudinally and placed in $15 \mathrm{~mL}$ tubes with $2 \mathrm{~mL}$ of ice-cold sterilized PBS. Tubes were inverted 20 times and vortexed for $10 \mathrm{~s}$ : the collected liquid represented the 'mucosal content'; (iii) finally, the 'epithelial layer' was recovered: the remaining tissue pieces were cut into 3-5 mm square patches, mixed with $10 \mathrm{~mL}$ of PBS containing $0.5 \mathrm{mM}$ DTT and $5 \mathrm{mM}$ EDTA, and incubated with constant shaking at $37{ }^{\circ} \mathrm{C}$ for $20 \mathrm{~min}$. Epithelial cells were recovered by pipetting for ten times and filtering the sample through a $70 \mu \mathrm{m}$ cell strainer to remove tissue fragments; cells were pelleted by centrifugation at $6000 \mathrm{~g}$ at $4{ }^{\circ} \mathrm{C}$ for $10 \mathrm{~min}$ [11]. As negative control, DAAO ${ }^{-/-}$knockout mice which do not express the flavoenzyme were used [20].

\section{Western blot analyses}

The presence of DAAO in the different gut samples was investigated by Western blot analyses using different antibodies: anti-hDAAO, diluted 1:3000 (Davids Biotechnologie, Regensburg, Germany); anti-hDAAO $C$-terminal, diluted 1:3000 (Davids Biotechnologie); anti-hDAAO $N$-terminal, diluted 1:250 (Davids Biotechnologie); anti-hDAAO diluted 1:1000 (Abcam, Cambridge, UK); anti-hDAAO, 
diluted 1:500 (Rockland, Limerick, PA, USA); anti-mDAAO $C$-terminal, diluted 1:500 (Santa Cruz Biotechnology, Dallas, TX, USA). Epithelial cells were homogenized in lysis buffer (150 mM sodium chloride, 1\% NP-40, $50 \mathrm{mM}$ Tris, $\mathrm{pH}$ 8.0, and a proteases' inhibitor cocktail), and luminal and mucosal contents isolated from the small intestine were sonicated and centrifuged. Protein level in supernatants was quantified using Bradford reagent. A cerebellar lysate was used as a positive control for the presence of DAAO. Supernatants were subjected to SDS-PAGE and proteins were transferred to PVDF membranes. Western blot analyses were performed as reported in Ref. [23]; densitometric analysis was performed to assess the amount of protein in the detected bands.

\section{nLC-MS/MS analysis}

To verify the presence of DAAO in the small intestine, tissue samples were analyzed by mass spectrometry. $160 \mu \mathrm{g}$ $(40 \times 4$ lanes $)$ of total proteins from different gut fractions were separated by SDS-PAGE and stained with colloidal Coomassie; the bands of interest (i.e., at the selected molecular mass values) were cut and stored in 5\% acetic acid for the identification by nLC-MS/MS. Each band was cut and digested in situ by trypsin sequence grade upon extraction with trichloroacetic acid and acetonitrile, reduction with $45 \mathrm{mM}$ dithiothreitol, and alkylation with $100 \mathrm{mM}$ iodoacetamide. MS/MS analysis was carried out by an LTQ-Orbitrap Velos (Thermo Fisher Sci., Waltham, MA, USA), as previously described [38]. Database search was performed using the Sequest search engine of Proteome Discoverer 1.4 (Thermo Fisher Sci.) against the Rodentia and OXDA mouse (P18894) Uniprot sequence databases. Only peptides with Xcorr $\geq 1.45$ and Confidence FDR $\leq 0.05$ were kept for the identification.

To confirm the presence of peptides originated from mouse DAAO, mucosal contents of proximal, medial, and distal small intestine of C57BL/6 J and C57BL/6 J $\mathrm{DAAO}^{-/-}$knock-out mice were analyzed by a mass spectrometry-based peptidomic approach. Samples were precipitated with two volumes of cold acetonitrile containing $0.1 \%$ of trifluoroacetic acid (stored at $-20{ }^{\circ} \mathrm{C}$ overnight) and centrifuged at 13,200 rpm for $30 \mathrm{~min}$ to remove proteins. The supernatant containing peptides and low-molecular-weight proteins were collected, dried (Speed Vacuum), dissolved in $1 \%(\mathrm{v} / \mathrm{v})$ formic acid, and desalted (Zip-Tip C18, Millipore) before mass spectrometric (MS) analysis. MS/MS analysis was carried out by a Orbitrap Fusion Tribrid mass spectrometer (Thermo Fisher Sci., Waltham, MA, USA), as previously described [39]. Data Base search was performed using the Sequest search engine of Proteome Discoverer 1.4 (Thermo Fisher Sci.) against OXDA mouse (P18894)
Uniprot sequence database. Only peptides with Xcorr $\geq 1.5$ and high confidence were kept for the identification.

\section{DAAO activity of intestinal samples}

With the aim to verify the presence of active DAAO in the intestinal fractions, two methods have been used: (a) native PAGE: gels were stained for DAAO activity based on the reduction of iodonitrotetrazolium salt, i.e., by incubating at $37^{\circ} \mathrm{C}$, the gel in $35 \mathrm{mM}$ sodium pyrophosphate, $\mathrm{pH} 8.5$, $0.2 \mathrm{mM}$ FAD, $28 \mathrm{mM}$ D-Ala, and $0.18 \mathrm{mM}$ iodonitrotetrazolium dissolved in ethanol [40]; (b) Amplex UltraRed (Thermo Fisher Sci.) detecting hydrogen peroxide formation [23]. Controls were performed by adding the DAAO specific inhibitor CBIO or removing the substrate in the assay solution (negative controls), as well as using the recombinant hDAAO or mice cerebellum samples (positive controls).

Author contributions LP and GM conceived the experiments and interpreted the results. GM performed the biochemical experiments. EN and GM identified and studied the antimicrobial peptides. EN, VC, and MA carried out and interpreted the microbiology experiments. SS, GM, and JPM performed the experiments on gut samples. GT and EM performed mass spectrometry experiments. GM and LP wrote the manuscript with the help of all authors that approved the final manuscript.

Funding Open Access funding provided by Università degli Studi dell'Insubria. This work was supported by Fondazione Cariplo (Grant 2018-2786). LP and SS thank the support of Fondo di Ateneo per la Ricerca. J-P.M. thanks the support of CNRS, ENS Paris-Saclay and Université Paris-Saclay.

Data availability The datasets generated during and/or analysed during the current study are available from the corresponding author on reasonable request.

\section{Compliance with ethical standards}

Conflict of interest The authors declare that they have no conflict of interest.

Ethical approval All experiments on animals were conducted in accordance with Italian (Decr. Leg. 4.03.2014 n. 26) and French directives on animal experimentation and following the Directive 2010/63/ EU of the European Parliament, and were approved by the University Paris-Saclay (accreditation number C92-019-01) and Ethics Committee (authorization No. 75 1273).

Open Access This article is licensed under a Creative Commons Attribution 4.0 International License, which permits use, sharing, adaptation, distribution and reproduction in any medium or format, as long as you give appropriate credit to the original author(s) and the source, provide a link to the Creative Commons licence, and indicate if changes were made. The images or other third party material in this article are included in the article's Creative Commons licence, unless indicated otherwise in a credit line to the material. If material is not included in the article's Creative Commons licence and your intended use is not permitted by statutory regulation or exceeds the permitted use, you will 
need to obtain permission directly from the copyright holder. To view a copy of this licence, visit http://creativecommons.org/licenses/by/4.0/.

\section{References}

1. Marcone GL, Rosini E, Crespi E, Pollegioni L (2020) D-amino acids in foods. Appl Microbiol Biotechnol 104(2):555-574. https ://doi.org/10.1007/s00253-019-10264-9

2. De Jonge BL, Gage D, Xu N (2002) The carboxyl terminus of peptidoglycan stem peptides is a determinant for methicillin resistance in Staphylococcus aureus. Antimicrob Agents Chemother 46(10):3151-3155. https://doi.org/10.1128/ aac.46.10.3151-3155.2002

3. Cava F, de Pedro MA, Lam H, Davis BM, Waldor MK (2011) Distinct pathways for modification of the bacterial cell wall by non-canonical D-amino acids. EMBO J 30(16):3442-3453. https ://doi.org/10.1038/emboj.2011.246

4. Pidgeon SE, Fura JM, Leon W, Birabaharan M, Vezenov D, Pires MM (2015) Metabolic profiling of bacteria by unnatural C-terminated D-amino acids. Angew Chem Int Ed Engl 54(21):6158-6162. https://doi.org/10.1002/anie.201409927

5. Pollegioni L, Piubelli L, Sacchi S, Pilone MS, Molla G (2007) Physiological functions of D-amino acid oxidases: from yeast to humans. Cell Mol Life Sci 64(11):1373-1394. https://doi. org/10.1007/s00018-007-6558-4

6. Sacchi S, Caldinelli L, Cappelletti P, Pollegioni L, Molla G (2012) Structure-function relationships in human D-amino acid oxidase. Amino Acids 43(5):1833-1850. https://doi. org/10.1007/s00726-012-1345-4

7. Mothet JP, Le Bail M, Billard JM (2015) Time and space profiling of NMDA receptor co-agonist functions. J Neurochem 135(2):210-225. https://doi.org/10.1111/jnc.13204

8. Wolosker H (2018) The neurobiology of D-serine signaling. Adv Pharmacol 82:325-348. https://doi.org/10.1016/ bs.apha.2017.08.010

9. Balu DT, Coyle JT (2015) The NMDA receptor 'glycine modulatory site' in schizophrenia: D-serine, glycine, and beyond. Curr Opin Pharmacol 20:109-115. https://doi.org/10.1016/j. coph.2014.12.004

10. Koga R, Miyoshi Y, Sakaue H, Hamase K, Konno R (2017) Mouse D-amino-acid oxidase: distribution and physiological substrates. Front Mol Biosci 4:82. https://doi.org/10.3389/fmolb .2017 .00082

11. Sasabe J, Miyoshi Y, Rakoff-Nahoum S et al (2016) Interplay between microbial D-amino acids and host D-amino acid oxidase modifies murine mucosal defence and gut microbiota. Nat Microbiol 1(10):16125. https://doi.org/10.1038/nmicrobiol 2016.125

12. Sasabe J, Suzuki M (2018) Emerging role of D-amino acid metabolism in the innate defense. Front Microbiol 9:933. https://doi. org/10.3389/fmicb.2018.00933

13. Pane K, Durante L, Crescenzi O et al (2017) Antimicrobial potency of cationic antimicrobial peptides can be predicted from their amino acid composition: application to the detection of "cryptic" antimicrobial peptides. J Theor Biol 419:254-265. https ://doi.org/10.1016/j.jtbi.2017.02.012

14. Molla G, Sacchi S, Bernasconi M, Pilone MS, Fukui K, Pollegioni L (2006) Characterization of human D-amino acid oxidase. FEBS Lett 580(9):2358-2364. https://doi.org/10.1016/j.febsl et.2006.03.045

15. De Marco A, Deuerling E, Mogk A, Tomoyasu T, Bukau B (2007) Chaperone-based procedure to increase yields of soluble recombinant proteins produced in E. coli. BMC Biotechnol 7:32. https://doi.org/10.1186/1472-6750-7-32

16. Caldinelli L, Molla G, Sacchi S, Pilone MS, Pollegioni L (2009) Relevance of weak flavin binding in human D-amino acid oxidase. Protein Sci 18(4):801-810. https://doi.org/10.1002/pro.86

17. Rossmann MG, Moras D, Olsen KW (1974) Chemical and biological evolution of nucleotide-binding protein. Nature 250(463):194-199. https://doi.org/10.1038/250194a0

18. Wierenga RK, Terpstra P, Hol WG (1986) Prediction of the occurrence of the ADP-binding beta alpha beta-fold in proteins, using an amino acid sequence fingerprint. J Mol Biol 187(1):101-107. https://doi.org/10.1016/0022-2836(86)90409-2

19. Mothet JP, Billard JM, Pollegioni L, Coyle JT, Sweedler JV (2019) Investigating brain D-serine: advocacy for good practices. Acta Physiol (Oxf) 226(1):e13257. https://doi.org/10.1111/apha.13257

20. Schweimer JV, Coullon GS, Betts JF et al (2014) Increased burstfiring of ventral tegmental area dopaminergic neurons in D-amino acid oxidase knockout mice in vivo. Eur J Neurosci 40(7):2999_ 3009. https://doi.org/10.1111/ejn.12667

21. Ferraris D, Duvall B, Ko YS et al (2008) Synthesis and biological evaluation of D-amino acid oxidase inhibitors. J Med Chem 51(12):3357-3359. https://doi.org/10.1021/jm800200u

22. Moreno S, Nardacci R, Cimini A, Cerù MP (1999) Immunocytochemical localization of D-amino acid oxidase in rat brain. $\mathrm{J}$ Neurocytol 28(3):169-185. https://doi.org/10.1023/a:1007064504 007

23. Sacchi S, Bernasconi M, Martineau M et al (2008) pLG72 modulates intracellular D-serine levels through its interaction with D-amino acid oxidase: effect on schizophrenia susceptibility. J Biol Chem 283(32):22244-22256. https://doi.org/10.1074/jbc.M7091 53200

24. Cappelletti P, Campomenosi P, Pollegioni L, Sacchi S (2014) The degradation (by distinct pathways) of human D-amino acid oxidase and its interacting partner pLG72-two key proteins in D-serine catabolism in the brain. FEBS J 281(3):708-723. https://doi. org/10.1111/febs. 12616

25. Sacchi S, Cappelletti P, Giovannardi S, Pollegioni L (2011) Evidence for the interaction of D-amino acid oxidase with pLG72 in a glial cell line. Mol Cell Neurosci 48(1):20-28. https://doi. org/10.1016/j.mcn.2011.06.001

26. Luks L, Maier MY, Sacchi S, Pollegioni L, Dietrich DR (2017) Understanding renal nuclear protein accumulation: an in vitro approach to explain an in vivo phenomenon. Arch Toxicol 91(11):3599-3611. https://doi.org/10.1007/s00204-017-1970-5

27. Marcone GL, Binda E, Rosini E, Abbondi M, Pollegioni L (2019) Antibacterial properties of D-amino acid oxidase: impact on the food industry. Front Microbiol 10:2786. https://doi.org/10.3389/ fmicb.2019.02786

28. Kim SH, Shishido Y, Sogabe H et al (2019) Age- and genderdependent D-amino acid oxidase activity in mouse brain and peripheral tissues: implication for aging and neurodegeneration. J Biochem 166(2):187-196. https://doi.org/10.1093/jb/mvz025

29. Bosso A, Pirone L, Gaglione R et al (2017) A new cryptic host defense peptide identified in human 11-hydroxysteroid dehydrogenase-1 $\beta$-like: from in silico identification to experimental evidence. Biochim Biophys Acta Gen Subj 1861(9):2342-2353. https ://doi.org/10.1016/j.bbagen.2017.04.009

30. Pane K, Cafaro V, Avitabile A et al (2018) Identification of novel cryptic multifunctional antimicrobial peptides from the human stomach enabled by a computational-experimental platform. ACS Synth Biol 7(9):2105-2115. https://doi.org/10.1021/acssy nbio. 8 b00084

31. Pizzo E, Pane K, Bosso A et al (2018) Novel bioactive peptides from PD-L1/2, a type 1 ribosome inactivating protein from phytolacca dioica L. Evaluation of their antimicrobial properties and anti-biofilm activities. Biochim Biophys Acta 
Biomembr 1860(7):1425-1435. https://doi.org/10.1016/j.bbame m.2018.04.010

32. Cline MJ, Lehrer RI (1969) D-amino acid oxidase in leukocytes: a possible D-amino-acid-linked antimicrobial system. Proc Natl Acad Sci USA 62(3):756-763. https://doi.org/10.1073/ pnas.62.3.756

33. Nakamura H, Fang J, Maeda H (2012) Protective role of D-amino acid oxidase against Staphylococcus aureus infection. Infect Immun 80(4):1546-1553. https://doi.org/10.1128/IAI.06214-11

34. Chang $\mathrm{CH}$, Lin CH, Lane HY (2020) D-glutamate and gut microbiota in Alzheimer's disease. Int J Mol Sci 21(8):2676. https://doi. org/10.3390/ijms21082676

35. Piubelli L, Pollegioni L, Rabattoni V et al (2021) Serum D-serine levels are altered in early phases of Alzheimer's disease: towards a precocious biomarker. Transl Psych. https://doi.org/10.1038/s4139 8-021-01202-3

36. Vaishnava S, Yamamoto M, Severson KM et al (2011) The antibacterial lectin RegIIIgamma promotes the spatial segregation of microbiota and host in the intestine. Science 334(6053):255-258. https://doi.org/10.1126/science. 1209791

37. Roche JK (2001) Isolation of a purified epithelial cell population from human colon. Methods Mol Med 50:15-20. https://doi. org/10.1385/1-59259-084-5:15
38. Dell'Orco M, Milani P, Arrigoni L et al (2016) Hydrogen peroxide-mediated induction of SOD1 gene transcription is independent from Nrf2 in a cellular model of neurodegeneration. Biochim Biophys Acta 1859(2):315-323. https://doi.org/10.1016/j.bbagr m.2015.11.009

39. Maffioli E, Galli A, Nonnis S, Marku A, Negri A, Piazzoni C, Milani P, Lenardi L, Perego C, Tedeschi G (2020) Proteomic analysis reveals a mitochondrial remodelling of $\beta \mathrm{TC} 3$ cells in response to nanotopography. Front Cell Dev Biol. https://doi.org/10.3389/ fcell.2020.00508 (in press)

40. Piubelli L, Molla G, Caldinelli L, Pilone MS, Pollegioni L (2003) Dissection of the structural determinants involved in formation of the dimeric form of D-amino acid oxidase from Rhodotorula gracilis: role of the size of the betaF5-betaF6 loop. Protein Eng 16(12):1063-1069. https://doi.org/10.1093/protein/gzg125

Publisher's Note Springer Nature remains neutral with regard to jurisdictional claims in published maps and institutional affiliations. 